\title{
Suplementasi Sari Belimbing Wuluh (Averrhoa bilimbi L.) dalam Air Minum terhadap Produktivitas Puyuh dan Kualitas Telur
}

Supplementation of Averrhoa bilimbi L. Juice in Drinking Water on Performance and Physical Quality of Quail Egg

\author{
L Wahyuni, M R Ramdhani, N O Imama, V E Larasati, A R Fahmi*, W Hermana
}

Corresponding email: lylya024@gmail.com

Departemen Ilmu Nutrisi dan Teknologi Pakan, Fakultas Peternakan, Institut Pertanian Bogor (Bogor Agricultural University/IPB University)

\begin{abstract}
Supplementation of Averrhoa bilimbi L. juice which contains vitamin C and organic acid in drinking water has been proposed to reduce the effect of heat stress on the quail layer. So this is expected to increase the productivity of quail and their egg quality. The aim of this research was to determine the effect of $A$. bilimbi juice supplementation in quail drinking water on quail performance, physical quality of egg, and egg yolk antioxidant level. Two hundred and forty birds aged 4-5 weeks were maintained for 42 days. A Completely Randomized Design was used in this study with 4 treatments. Each treatment has 4 replications and 15 quails in each replications. Addition of Vita Chick (P0) to the drinking water was used as a positive control. The treatments given were the addition of $A$. bilimbi extract with different levels of $0 \%$ (P1), 2.5\% (P2), and 5\% (P3) respectively. The variables observed were quail performance, physical egg quality, and egg yolk antioxidant levels. The results showed that the physical quality of quail eggs obtained were the weight of albumen and egg shells did not different all treatments. The addition of $A$. bilimbi juice in drinking water has affected on the weight and percentage of albumen, eggshell, and Haugh Unit. The addition of $2.5 \%$ of A.bilimbi juice (P2) had the lowest feed conversion ratio (FCR). However it showed the highest Haugh Unit number of the egg. There was no different effect of the highest dose of $A$. bilimbi juice (5\%, P3) on the egg yolk antioxidant activity and capacity ( $41.54 \%$ and $23.91 \mathrm{ppm}$ respectively). It was concluded that supplementation of $A$. bilimbi juice in drinker water could changed to antistress drug commercial.
\end{abstract}

Key words: bilimbi (Averrhoa bilimbi L.), egg quality, egg yolk antioxidant, quail performance

\section{ABSTRAK}

Suplementasi sari belimbing wuluh dengan kandungan nutrien tertentu yaitu vitamin $\mathrm{C}$ dan asam organik dalam air minum puyuh petelur bertujuan untuk mengurangi efek negatif akibat stres panas sehingga dapat meningkatkan produktivitas puyuh dan kualitas telurnya. Penelitian ini bertujuan untuk mengetahui pengaruh pemberian sari belimbing wuluh dalam air minum puyuh terhadap performa puyuh, kualitas fisik telur dan kadar antioksidan kuning telur. Jumlah puyuh yang digunakan sebanyak 240 ekor berumur 4-5 minggu dipelihara selama 42 hari. Rancangan Acak Lengkap dengan 4 perlakuan digunakan pada penelitian ini dan diuji Duncan apabila hasilnya berbeda nyata. Setiap perlakuan diulang sebanyak 4 ulangan dan 15 ekor pada setiap ulangan. Penambahan Vita Chick (P0) dalam air minum digunakan sebagai kontrol positif. Perlakuan yang diberikan adalah penambahan sari belimbing wuluh dengan level yang berbeda yaitu (P1 = 0\%; P2 : 2,5\%; dan P3: 5\%). Peubah yang diamati adalah performa puyuh, kualitas fisik telur, dan kadar antioksidan kuning telur. Hasil penelitian menunjukkan bahwa penambahan sari belimbing wuluh berpengaruh nyata $(\mathrm{p}<0,05)$ terhadap bobot dan persentase putih telur, bobot dan persentase kerabang telur dan Haugh Unit. Penambahan 2,5\% sari belimbing wuluh (P2) menghasilan konversi pakan terendah dengan nilai Haugh Unit tertinggi. Perlakuan dengan dosis tertinggi (5\%, P3) belum efektif meningkatkan kadar antioksidan kuning telur. Pada tingkat 5\% sari belimbing wuluh menghasilkan aktivitas dan kapasitas antioksidan terendah sebesar $41,54 \%$ dan 23,91 ppm.

Kata kunci: antioksidan kuning telur, belimbing wuluh (Averrhoa bilimbi L.), kualitas telur, performa puyuh 


\section{PENDAHULUAN}

Peternakan merupakan sektor yang berperan penting dalam memasok kebutuhan pangan nasional. Pemenuhan kebutuhan protein hewani salah satunya berasal dari ternak unggas yang dapat berproduksi dalam jangka waktu pendek. Puyuh merupakan salah satu jenis unggas yang dapat dikembangkan untuk memenuhi kebutuhan pangan sumber protein hewani dengan keunggulannya yaitu mampu berproduksi pada umur 41 hari dan menghasilkan telur sebanyak 250-300 butir per tahun (Subekti \& Dewi 2013). Unggas tidak memiliki kelenjar keringat untuk mengeluarkan panas tubuhnya sehingga menyebabkan rentan terhadap stres panas dan produktivitasnya menurun. Ternak stres dapat diketahui dari perilakunya seperti gelisah, konsumsi air tinggi, nafsu makan menurun, mengepakkan sayap ke lantai, dan terengah-engah (Tamzil et al. 2014). Pakan dengan kandungan nutrisi yang lengkap dibutuhkan untuk mencukupi kebutuhan ternak baik dalam kebutuhan dasar tubuh atau menghasilkan produk. Selain dari pakan, kebutuhan nutrisi ternak juga dapat dipenuhi melalui penambahan suplemen. Namun apabila kondisi lingkungan (suhu dan kelembaban) yang tidak mendukung dapat menyebabkan ternak stres dan menghambat pertumbuhan ternak. Suhu lingkungan yang ideal untuk pertumbuhan puyuh adalah $20^{\circ} \mathrm{C}-25^{\circ} \mathrm{C}$ dengan kelembaban udara 50\% - 70\% (Borges et al. 2004). Suhu di Indonesia yang beriklim tropis cenderung lebih tinggi yaitu $24^{\circ} \mathrm{C}-32^{\circ} \mathrm{C}$ dengan kelembaban udara $77 \%-85 \%$ (Badan Pusat Statistik 2016), perbedaan tersebut menyebabkan pertumbuhan puyuh kurang optimal.

Antibiotik komersial digunakan untuk meningkatkan daya tahan tubuh dan meningkatkan penyerapan nutrien dalam usus halus ternak guna memperbaiki performa ternak. Namun penggunaannya yang terus-menerus dapat menyebabkan residu pada produk yang dihasilkan. Dibutuhkan alternatif pengganti antibiotik dengan zat alami untuk menekan efek negatif tersebut. Belimbing wuluh (Averrhoa bilimbi L.) merupakan tanaman lokal yang mengandung flavonoid, triterpenoid, saponin, vitamin C, asam sitrat (Kumar et al. 2013). Vitamin C merupakan antioksidan yang terbukti dapat menangkal stres pada ayam yang dipelihara pada suhu tinggi (Tamzil et al. 2014). Selain itu, belimbing wuluh juga mengandung berbagai macam asam organik yang dapat digunakan sebagai acidifier alami untuk meningkatkan penyerapan nutrien ternak. Menurut penelitian Boling et al. (2001), penggunaan asam organik dapat menurunkan pH pada saluran pencernaan ayam, menekan bakteri patogen dan meningkatkan pertumbuhan bakteri non patogen sehingga berpengaruh terhadap efisiensi penggunaan pakan.

Penggunaan sari belimbing wuluh dalam penelitian ini bertujuan untuk mengetahui pengaruh pemberian sari belimbing wuluh dalam air minum puyuh terhadap performa puyuh, kualitas fisik telur dan kadar antioksidan kuning telur.
Tabel 1 Kandungan nutrien dalam ransum komersial puyuh layer

\begin{tabular}{lc}
\hline Kandungan nutrien & Jumlah $^{1)}$ \\
\hline Kadar air (\%) & Max. 12 \\
Abu (\%) & Max. 8 \\
Protein kasar (\%) & $21-23$ \\
Lemak kasar (\%) & Min. 5 \\
Serat kasar (\%) & Max. 5 \\
Ca & $0,8-1,1$ \\
P & 0,5 \\
\hline 1) sesuai label &
\end{tabular}

\section{METODE}

\section{Ternak dan Ransum}

Puyuh betina periode siap bertelur berumur sekitar 4-5 minggu sebanyak 240 ekor digunakan pada penelitian ini yang dibagi ke dalam 4 perlakuan dan 4 ulangan, setiap ulangan 15 ekor. Pemeliharaan selama 42 hari dilakukan di Peternakan Puyuh Slamet Quail Farm (SQF) Sukabumi. Ransum yang diberikan adalah ransum komersial dengan kandungan nutrien pada Tabel 1.

\section{Kandang}

Kandang koloni petelur yang dipakai terbuat dari papan triplek dan kawat berbentuk persegi yang terdiri atas 4 kotak dengan masing-masing kotak terdapat 1 tempat pakan dan 1 tempat minum. Setiap kotak kandang berukuran $100 \mathrm{~cm} \times 30 \mathrm{~cm} \times 30 \mathrm{~cm}$.

\section{Pembuatan dan Perlakuan Sari Belimbing Wuluh}

Belimbing wuluh (Averrhoa bilimbi L.) diperoleh dari kebun penelitian Cikabayan, buah yang diambil adalah yang sudah cukup matang dengan ciri-ciri berwarna hijau kekuningan. Belimbing wuluh dicuci dan dikeringkan kemudian dipotong berukuran sekitar 0,5 cm dan dihaluskan menggunakan blender selama 1 menit dan disaring sampai diperoleh sarinya. Diambil sampel sari belimbing wuluh murni untuk dianalisis kandungan fitokimia dan hasil analisis dapat dilihat pada Tabel 2.

Tabel 2 Kandungan nutrien Vita Chick per $1 \mathrm{~g}$

\begin{tabular}{lc}
\hline Kandungan nutrien & Jumlah $^{1)}$ \\
\hline Bacitracin (mg) & 35 \\
Vitamin A (IU) & 5000 \\
Vitamin D3 (IU) & 500 \\
Vitamin E (IU) & 2,5 \\
Vitamin K3 (mg) & 1 \\
Vitamin B1 (mg) & 2 \\
Vitamin B2 (mg) & 4 \\
Vitamin B12 (mg) & 0,001 \\
Vitamin C (mg) & 20 \\
Nicotinic acid (mg) & 15 \\
Alcium-D-panthothenate (mg) & 5 \\
\hline 1) sesuai label &
\end{tabular}


Selanjutnya sari belimbing wuluh disimpan dalam freezer dan dicairkan ketika akan digunakan. Perlakuan kontrol yaitu penggunaan obat anti stress komersial (vita Chick) yang diberikan dengan perbandingan $0,7 \mathrm{~g}$ dalam 1 liter air minum. Kandungan nutrien vita chick tecantum pada Tabel 2, sedangkan untuk perlakuan sari belimbing wuluh, diberikan dengan dosis setiap 1 liter dengan campuran sari belimbing wuluh mengikuti persentase. Pemberian sari belimbing wuluh dengan dosis sebagai berikut :

P0 : Pakan komersil + air minum dengan Vita Chick

P1 : Pakan komersil + air minum dengan $0 \%$ sari belimbing wuluh

P2 : Pakan komersil + air minum dengan 2,5\% sari belimbing wuluh

P3 : Pakan komersil + air minum dengan 5\% sari belimbing wuluh

\section{Pemeliharaan dan Pengambilan Data}

Puyuh diadaptasikan dengan perlakuan selama 7 hari awal pemelihaan dan dipelihara selama 6 minggu dengan pemberian perlakuan sari belimbing wuluh sebanyak $2 \mathrm{x}$ dalam seminggu yaitu hari Selasa dan Jumat dengan pemberian sepanjang hari. Ransum diberikan setiap hari

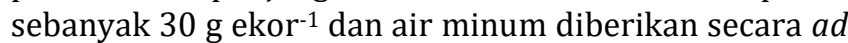
libitum. Pemberian pakan dan air minum dilakukan pada pagi hari pukul 07.00-08.00 WIB. Pengukuran konsumsi pakan, konsumsi air dan produksi telur (quail day production) dilakukan setiap hari. Pengukuran suhu dan kelembaban dilakukan pada pagi (pukul 17.00-18.00 WIB), siang (pukul 17.00-18.00 WIB), dan sore (pukul 17.00-18.00 WIB). Sebanyak 3-5 butir telur diambil di akhir pemeliharaan untuk diukur kualitas fisik dan diambil 1 sampel kuning telur secara acak untuk dianalisis kadar antioksidan.

\section{Rancangan dan Analisis Data}

Rancangan percobaan yang digunakan adalah Rancangan Acak Lengkap (RAL) dengan 4 perlakuan, 4 ulangan, masing-masing ulangan tediri atas 15 ekor. Data yang diperoleh dianalisis dengan sidik ragam Analysis of Variance untuk mengetahui hubungan antara perlakuan dan peubah yang diamati diuji Duncan apabila hasilnya berbeda nyata.

\section{Peubah Performa yang Diamati \\ Rataan Konsumsi Pakan (g/e) Jumlah pakan yang diberikan (g)-sisa pakan (g) Jumlah puyuh (ekor) \\ Rataan Konsumsi Air (ml/e) Jumlah air yang diberikan $(\mathrm{ml})$-sisa air $(\mathrm{ml})$ Jumlah puyuh (ekor) \\ Produksi Telur Harian (Quail DayProduction) (\%)= $\frac{\text { Jumlah telur yang dihasilkan (butir) }}{\text { Jumlah puyuh (ekor) }} \times 100 \%$ \\ Konversi Pakan $\underline{\text { Jumlah pakan yang diberikan }(\mathrm{g})}$ Bobot telur (g)}

\section{Pengukuran Kualitas Fisik Telur}

Pengukuran kualitas eksternal telur puyuh dilakukan dengan penimbangan bobot utuh telur, tinggi telur, dan lebar telur. Pengukuran kualitas internal telur dilakukan dengan pemecahan telur kemudian diukur tinggi putih dan kuning telur, diameter putih dan kuning telur, bobot putih dan kuning telur, bobot kerabang, tebal kerabang di bagian runcing, tengah, dan runcing, warna kuning telur dibandingkan dengan warna standar kuning telur Roche Egg Yolk Colour Fan. Data yang diperoleh dihitung persentase, Haugh Unit (HU), dan Indeks Kuning Telur (IKT).

$$
\begin{aligned}
& \text { HU }=100 \log \left(\mathrm{h}+7,57-1,7 \mathrm{~W}^{0,37}\right) \\
& \text { Keterangan : } \\
& \mathrm{HU}=\text { Haugh Unit } \\
& \mathrm{H}=\text { tinggi putih telur }(\mathrm{mm}) \\
& \mathrm{W}=\text { bobot telur }(\mathrm{g}) \\
& \mathrm{IKT}=\frac{\text { Tinggi kuning telur }(\mathrm{mm})}{\text { Diameter kuning telur }(\mathrm{mm})}
\end{aligned}
$$

\section{Kadar Antioksidan Kuning Telur}

Kuning telur diambil secara acak dari setiap perlakuan pada akhir pemeliharaan dan dianalisis aktivitas dan kapasitas antioksidan. Hasil yang diperoleh dianalisis secara deskriptif. Pengukuran kadar antioksidan menggunakan metode DPPH menurut Tangkanakul et al. (2009). Sampel diekstraksi menggunakan $100 \%$ etanol pada suhu kamar. Rasio sampel dan metanol adalah 1 : 10. Supernatan disimpan dalam botol tertutup dan diimpn pada suhu $-20^{\circ} \mathrm{C}$ sampai digunakan lebih lanjut untuk menentukan nilai aktivitas dan kandungan fenol total. Hasil ekstraksi sebanyak 0,15 ml ditambahkan ke dalam 0,9 ml larutan DPPH metanol 0,1 Mm. Setelah 20 menit, nilai absorbansi dari campuran tersebut dicatat pada $517 \mathrm{~nm}$. Metanol murni digunakan sebagai kontrol. Persentase aktivitas DPPH scavenging (\%SA) dikalkulasikan ke dalam persamaan $(1-\mathrm{X} / \mathrm{C}) * 100$, dimana $\mathrm{X}$ adalah nilai absorbansi dari ekstrak dan $\mathrm{C}$ adalah nilai absorbansi dari kontrol. Kapasitas antioksidan ditentukan berdasakan kemampuan bahan yang dieksrak untuk bereaksi dengan DPPH radikal bebas yang dibandingkan dengan kemampuan antioksidan. Kapasitas antioksidan disamakan dengan mg vitamin C (Vitamin C Equivalent)/100 g bahan yang diekstrak. Kurva standar vitamin $\mathrm{C}$ diperoleh dari DPPH \% SA ( $\mathrm{x}$ ) dengan konsentrasi vitamin $\mathrm{C}(\mathrm{y})$. Konsentrasi larutan vitamin $C$ yaitu 0,5; 1,0; 2,0 dan 2,5 mg $100 \mathrm{ml}^{-1}$ air suling. Persamaan regresi yang digunakan adalah y $=$ 0,0466x - 0,0474 (Tangkanakul et al. 2009)

\section{HASIL DAN PEMBAHASAN}

\section{Kandungan Fitokimia dalam Sari Belimbing Wuluh Senyawa fitokimia yang terdeteksi dalam sari belimbing wuluh murni (100\%) yaitu alkaloid, flavonoid, triterpenoid, dan saponin (Tabel 3). Zat aktif yang terkandung dari belimbing wuluh seperti flavonoid, triterpenoid, saponin, dan tanin dapat berperan sebagai}


Tabel 3 Kandungan fitokimia sari belimbing wuluh

\begin{tabular}{lc}
\hline Jenis fitokimia & Hasil $^{1}$ \\
\hline Alkaloid & ++ \\
Flavonoid & ++ \\
Phenol & - \\
Steroid & - \\
Triterpenoid & ++ \\
Tanin & - \\
Saponin & + \\
\hline - = tidak terdeteksi; + = positif lemah; ++ = positif; +++ = positif \\
kuat; ++++ positif sangat kuat \\
1)Hasil analisis Laboratorium Kimia Analitik, Fakultas Matematika \\
dan Ilmu Pengetahuan Alam, IPB
\end{tabular}

antibakteri dengan cara menghambat pertumbuhan bakteri.

Menurut Saputra \& Anggraini (2016), ekstrak belimbing wuluh dapat digunakan sebagai terapi nonfarmakologi untuk penyembuhan acne vulgaris atau jerawat akibat bakteri. Flavonoid bekerja dengan cara mendenaturasi protein, senyawa ini dapat membentuk ikatan kompleks dengan protein bakteri dengan ikatan hidrogen. Hal ini menyebabkan dinding sel dan membran sitoplasma bakteri tidak stabil dan fungi permeabilitas sel terganggu sehingga sel bakteri lisis akibat kematian sel. Triterpenoid dapat merusak fraksi lipid pada membran sitoplasma sel yang dapat mengakibatkan terbentuknya membran atau dinding sel terganggu sehingga pembentukan membran atau dinding sel tidak sempurna (Lathifah 2008).

\section{Performa Puyuh}

Perlakuan pemberian sari belimbing wuluh dalam air minum puyuh selama 6 minggu pemeliharaan tidak memberikan pengaruh yang nyata terhadap performa puyuh. Data penelitian performa disajikan pada Tabel 4.

Pemberian perlakuan tidak berpengaruh nyata terhadap konsumsi pakan. Hasil yang sama juga ditunjukkan dari penelitian Malinda et al. (2017) yang menyebutkan bahwa pemberian sari belimbing wuluh tidak memberikan pengaruh yang nyata terhadap konsumsi pakan, konsumsi air minum, pertambahan bobot badan dan konversi pakan. Data dari penelitian Malinda et al. (2017) konsumsi pakan puyuh sebanyak 15,54 - 16,09 g ekor $^{-1}$ hari $^{-1}$ dengan umur puyuh 2 - 6

Tabel 4 Performa puyuh selama 6 minggu pemeliharaan

\begin{tabular}{|c|c|c|c|c|}
\hline \multirow{2}{*}{ Jenis peubah } & \multicolumn{4}{|c|}{ Perlakuan } \\
\hline & PO & P1 & $\mathrm{P} 2$ & P3 \\
\hline Konsumsi pakan & $31,24 \pm$ & $30,02 \pm$ & $29,15 \pm$ & $29,75 \pm$ \\
\hline (g ekor-1 hari-1) & 1,29 & 1,43 & 0,83 & 1,32 \\
\hline Konsumsi air minum & $61,21 \pm$ & $60,61 \pm$ & $61,07 \pm$ & $62,77 \pm$ \\
\hline (ml ekor-1 hari ${ }^{-1}$ ) & 1,27 & 1,56 & 2,22 & 1,63 \\
\hline Produksi Telur (Quail & $67,86 \pm$ & $68,10 \pm$ & $65,75 \pm$ & $71,61 \pm$ \\
\hline Day Production) (\%) & 1,84 & 4,95 & 7,18 & 2,14 \\
\hline Konversi Pakan & $2,69 \pm 0,13$ & $2,60 \pm 0,12$ & $2,56 \pm 0,05$ & $2,59 \pm 0,10$ \\
\hline
\end{tabular}

minggu. Puyuh yang digunakan pada penelitian ini merupakan puyuh dalam fase produksi sehingga memerlukan pakan yang cukup tinggi untuk menghasilkan telur dan mencukupi kebutuhan nutrien dalam tubuh untuk kebutuhan pokoknya. Sesuai dengan penelitian Ramdhani (2017) bahwa konsumsi pakan semakin tinggi sejalan dengan bertambahnya umur puyuh.

Konsumsi air minum puyuh pada penelitian ini berkisar antara 60,61 $\pm 1,56-62,77 \pm 1,63$ ml ekor $^{-1}$ hari $^{-1}$. Penelitian Malinda et al. (2017) menyebutkan rataan konsumsi air minum puyuh dengan penambahan sari belimbing wuluh tertinggi pada dosis $1 \%$ pada air minum adalah 32,11 $\pm 1,03$ ml ekor-1 hari-1 $^{-1}$ dan semakin bertambah konsumsinya dengan pengurangan dosis yang diberikan. Hasil pada penelitian memiliki nilai yang jauh lebih tinggi dibandingkan Malinda et al. (2017). Hal tersebut menunjukkan bahwa penambahan sari belimbing wuluh dalam air minum puyuh tidak menurunkan palatabilitas akibat rasa asam. Tingginya konsumsi air minum hasil penelitian dibandingkan Malinda et al. (2017) diduga akibat tingginya suhu dan kelembaban lingkungan di sekitar kandang sehingga menyebabkan puyuh stres panas yang ditandai dengan puyuh yang menyebar di dalam kandang dan terlihat terengah-engah sehingga konsumsi air minum lebih banyak.

Suhu dan kelembaban kandang tidak stabil dan cenderung tinggi (Tabel 5). Menurut Peraturan Menteri Pertanian Nomor 05 (2008), suhu bagi puyuh untuk berproduksi optimal adalah $21^{\circ} \mathrm{C}-26,50^{\circ} \mathrm{C}$ dengan kelembaban 70\%-80\%. Pada penelitian suhu lingkungan $23,30^{\circ} \mathrm{C} \pm 0,75-29,90 \pm 0,72^{\circ} \mathrm{C}$ dengan kelembaban $72,30 \pm 3,21 \%-98,90 \pm 0,32 \%$. Menurut Widyastuti et al. (2014) puyuh tidak mengkonsumsi banyak air jika tidak dalam keadaan stres akibat suhu yang tinggi, konsumsi air yang tinggi dapat berdampak pada berkurangnya konsumsi pakan yang mengakibatkan menurunnya pertambahan berat badan puyuh. Hasil penelitian menunjukkan bahwa semua perlakuan tidak mempengaruhi konsumsi air minum dan konsumsi pakan serta tidak mempengaruhi produksi telur. Puyuh penelitian menghasilkan telur (Quail Day Production) mencapai 71,61 $22,14 \%$ (P3) (Tabel 4). Diduga untuk tetap mempertahankan produksi telur, puyuh mengkonsumsi pakan dalam jumlah yang tinggi dengan diimbangi konsumsi air yang tinggi. Menurut Fouladi et al. (2018), produksi telur puyuh dapat mencapai 83,58\% jika dipelihara pada suhu $21^{\circ} \mathrm{C} \pm 2,{ }^{\circ} \mathrm{C}$ dengan penambahan asam organik pada pakan.

Produksi telur puyuh yang dihasilkan berkisar antara 65,75 $\pm 7,18 \%-71,61 \pm 2,14 \%$ (Tabel 4). Menurut

Tabel 5 Suhu dan kelembaban kandang puyuh

\begin{tabular}{lcc}
\hline \multicolumn{1}{c}{ Waktu } & Suhu $\left({ }^{\circ} \mathrm{C}\right)$ & Kelembaban $(\%)$ \\
\hline Pagi & $23,30 \pm 0,75$ & $98,90 \pm 0,32$ \\
Siang & $29,90 \pm 0,72$ & $72,30 \pm 3,21$ \\
Sore & $24,70 \pm 0,92$ & $82,50 \pm 3,70$ \\
\hline
\end{tabular}


penelitian Hamdan \& Napirah (2018) produksi telur dapat mencapai $71,38 \pm 3,34 \%$ dengan menggunakan asam sitrat. Hasil tersebut menunjukkan penggunaan sari belimbing wuluh (P3) menghasilkan efek yang cukup baik seperti penggunaan asam sitrat komersial. Perlakuan pemberian sari belimbing wuluh dalam air minum sampai taraf 5\% (P3) menghasilkan produksi telur yang sama dengan perlakuan kontrol menggunakan vita chick (P0). Pakan yang digunakan untuk semua perlakuan sama sehingga produksi telur yang dihasilkan juga cenderung sama. Sesuai dengan Nuraini et al. (2012) kandungan protein yang sama dalam pakan akan menghasilkan produksi telur yang relatif sama.

Konversi pakan merupakan perbandingan jumlah pakan yang dibutuhkan ternak untuk menghasilkan satu satuan bobot telur. Konversi pakan pada penelitian berkisar antara 2,56 $\pm 0,05-2,69 \pm 0,13$. Menurut Sudrajat et el. (2014), konversi pakan puyuh fase bertelur mencapai angka 6,69 $\pm 1,88$. Semakin kecil nilai konversi pakan menunjukkan semakin baik tingkat efisiensi puyuh dalam memanfaatkan pakan yang dikonsumsi menjadi daging atau telur.

\section{Kualitas Fisik Telur}

Semua perlakuan menunjukkan perbedaan yang nyata $(p<0,05)$ terhadap rataan bobot dan persentase pada putih telur dan kerabang, nilai Haugh Unit (HU), dan indeks kuning telur (Tabel 6). Bobot telur, warna kuning telur, bobot dan persentase kuning telur, serta tebal kerabang menunjukkan perbedaan yang tidak nyata untuk semua perlakuan. Bobot telur pada seluruh perlakuan tidak jauh berbeda dari penelitian Suci et al. (2019) yang berada pada kisaran 12,13 $\pm 0,35$ $12,46 \pm 0,27 \mathrm{~g}$ butir $^{-1}$. Bobot telur dipengaruhi oleh peningkatan pemberian protein dalam pakan (Ardiansyah et al. 2016). Pakan yang diberikan selama pemeliharaan seragam, tidak ada peningkatan atau pengurangan kadar protein. Meskipun konsumsi puyuh cenderung tinggi (Tabel 3), namun tidak mempengaruhi bobot telur yang dihasilkan. Sesuai dengan penelitian Hamdan \& Napirah (2018), penambahan asam sitrat dalam pakan dengan level protein step down dapat meningkatkan produksi telur serta menekan konversi pakan namun tidak mempengaruhi perubahan bobot telur.

Skor warna kuning telur seragam pada penelitian yaitu 5, semakin tinggi skor warna kuning telur semakin diminati konsumen karena warnanya yang lebih cerah. Menurut Suci et al. (2019), intensitas warna kuning telur dipengaruhi oleh banyaknya $\beta$-caroten dari pakan yang dikonsumsi unggas, pigmen tersebut dapat berasal dari hijauan atau jagung kuning yang merupakan komposisi penyusun pakan. Skor yang tinggi dapat dihasilkan jika pakan yang diberikan dapat dicerna dengan baik. Skor yang dihasilkan dari penelitian lebih tinggi dari penelitian sebelumnya yang dilakukan oleh Suci et al. (2019) dengan rataan skor warna kuning telur yaitu 4 . Pemberian sari belimbing wuluh tidak memberikan pengaruh terhadap perbedaan skor warna kuning telur dan $\beta$-caroten yang terkandung dalam kuning telur
Tabel 6 Kualitas fisik telur puyuh

\begin{tabular}{|c|c|c|c|c|}
\hline \multirow{2}{*}{ Jenis peubah } & \multicolumn{4}{|c|}{ Perlakuan } \\
\hline & P0 & P1 & $\mathrm{P} 2$ & P3 \\
\hline Bobot telur (g) & $12,39 \pm 0,41$ & $12,53 \pm 0,23$ & $12,48 \pm 0,03$ & $12,70 \pm 0,41$ \\
\hline $\begin{array}{l}\text { Skor warna kuning } \\
\text { telur }\end{array}$ & 5 & 5 & 5 & 5 \\
\hline \multicolumn{5}{|l|}{ Kuning telur } \\
\hline Bobot (g) & $3,89 \pm 0,29$ & $4,10 \pm 0,23$ & $3,94 \pm 0,10$ & $4,16 \pm 0,28$ \\
\hline Persentase (\%) & $31,41 \pm 2,13$ & $32,69 \pm 1,50$ & $31,54 \pm 0,88$ & $32,74 \pm 2,13$ \\
\hline \multicolumn{5}{|l|}{ Putih telur } \\
\hline Bobot (g) & $6,03 \pm 0,36^{a b}$ & $5,82 \pm 0,46^{b}$ & $6,50 \pm 0,14^{a}$ & $5,73 \pm 0,27^{b}$ \\
\hline \multirow[t]{2}{*}{ Persentase (\%) } & $48,66 \pm$ & $46,44 \pm$ & $52,00 \pm$ & $45,08 \pm$ \\
\hline & $3,10^{\mathrm{ab}}$ & $3,15^{b}$ & $1,15^{\mathrm{a}}$ & $1,07^{b}$ \\
\hline \multicolumn{5}{|l|}{ Kerabang telur } \\
\hline Bobot (g) & $1,36 \pm 0,10^{a b}$ & $1,43 \pm 0,07^{a}$ & $1,23 \pm 0,16^{b}$ & $1,50 \pm 0,04$ \\
\hline \multirow[t]{2}{*}{ Persentase (\%) } & $11,00 \pm$ & $11,44 \pm$ & $9,99 \pm$ & $11,83 \pm$ \\
\hline & $0,54^{\mathrm{ab}}$ & $0,57^{a}$ & $1,29^{b}$ & $0,39^{a}$ \\
\hline Teba & $0,17 \pm 0,10$ & $0,22 \pm 0,12$ & $0,17 \pm 0,01$ & $0,16 \pm 0,01$ \\
\hline \multirow[t]{2}{*}{$\mathrm{HU}$} & $91,16 \pm$ & $86,00 \pm$ & $93,46 \pm$ & $89,47 \pm$ \\
\hline & $1,63^{\mathrm{ab}}$ & $1,93^{c}$ & $1,05^{a}$ & $1,63^{b}$ \\
\hline IKT & $77,67 \pm 2,43$ & $77,49 \pm 2,06$ & $75,90 \pm 1,457$ & $78,88 \pm 2,85$ \\
\hline
\end{tabular}

Perbedaan huruf kecil pada baris yang sama menunjukkan perbedaan yang nyata $(\mathrm{p}<0,05)$ menurut uji Duncan

P0 = Vita Chick dalam air minum; P1 = air minum tanpa sari belimbing wuluh ; P2 $=2,5 \%$ sari belimbing wuluh dalam air minum; P3 $=5 \%$ sari belimbing wuluh dalam air minum

diduga hanya berasal dari pakan komersial yang diberikan.

Bobot dan persentase kuning telur disajikan pada Tabel 6 dengan nilai tertinggi dari perlakuan sari belimbing wuluh 5\% (P3) dengan bobot dan persentasenya $4,16 \pm 0,28 \mathrm{~g}$ dan $32,74 \pm 2,13 \%$. Tidak berbeda jauh dari penelitian Nastiti et al. (2014) yang menyatakan bobot kuning telur puyuh berumur 10-12 minggu dengan perlakuan pakan yang cukup beragam yaitu dari dedak gandum kasar dan daun mengkudu berkisar antara 3,21 $\pm 0,18 \mathrm{~g}-3,36 \pm 0,14 \mathrm{~g}$ dengan persentase $29,99 \pm 1,22 \%$ - 30,89 $\pm 0,55 \%$. Penambahan sari belimbing wuluh tidak mengganggu pembentukan kuning telur puyuh penelitian karena hasilnya yang cenderung lebih tinggi dari hasil perlakuan pakan yang beragam dari penelitian Nastiti (2017). Rataan bobot dan persentase putih telur tertinggi pada perlakuan P2 sebesar 6,50 g \pm 0,14 g dengan persentase $52 \% \pm 1,15 \%$. Tingginya rataan bobot dan persentase putih telur pada P2 diduga terjadi penyerapan nutrien pakan sebagai bahan pembentukan putih telur yang lebih tinggi. Kandungan asam organik dalam sari belimbing wuluh yang mampu mengoptimalkan penyerapan yang terjadi di usus halus dengan pemberian taraf 2,5\%. Asam organik yang diberikan pada ternak mampu meningkatkan kecernaan protein dan karbohidrat (Emma et al. 2013). Buah belimbing wuluh mengandung beberapa jenis asam organik yaitu asam asetat, asam sitrat, asam format, asam laktat dan asam oksalat dengan kandungan asam dominan asam sitrat sebanyak 92,6133,8 meq asam $100 \mathrm{~g}^{-1}$ total padatan (Subhadrabandhu 2001).

Asam organik berperan sebagai acidifier alami yang menurunkan tingkat keasaman dalam saluran 
pencernaan. Menurut Chowdhury et al. (2009), asam sitrat dapat menyebabkan perubahan tingkat keasaman pada saluran pencernaan menjadi 3,4-4,0. Kondisi tersebut sesuai untuk perkembangan bakteri Lactobacilli, namun tidak sesuai untuk perkembangan $E$. coli dan Salmonella sp, sehingga penyerapan nutrien dari pakan dapat lebih optimal. Suasana asam dapat mengaktifkan pepsinogen menjadi enzim pepsin yang dapat memecah molekul kompleks protein menjadi molekul yang lebih sederhana sehingga penyerapan protein pakan meningkat (Ensminger et al. 1990). Penelitian Fouladi et al. (2018), pemberian asam organik dapat menurunkan populasi bakteri E.coli dan Salmonella secara signifikan.

Rataan bobot dan persentase kerabang telur puyuh pada penelitian disajikan pada Tabel 6 dengan nilai terendah pada perlakuan penambahan 2,5\% sari belimbing wuluh (P2) dan nilai tertinggi pada $5 \%$ sari belimbing wuluh (P3). Hasil penelitian tidak berbeda jauh dari penelitian Nastiti et al. (2014) yang menggunakan puyuh umur 10-12 minggu menghasilkan bobot kerabang antara 1,27 $\pm 0,01 \mathrm{~g}-1,33 \pm 0,06 \mathrm{~g}$ dengan persentase antara 11,99 $\pm 0,15 \%-12,47 \pm 0,58 \%$. Penambahan sari belimbing wuluh tidak mengganggu proses pembentukan kerabang telur. Belimbing wuluh mengandung berbagai mineral seperti $\mathrm{Ca}, \mathrm{P}$, dan I (Kumar et al. 2013). Mineral penyusun kerabang diduga dominan berasal dari pakan yang diberikan. Tingginya konsumsi pakan mempengaruhi bobot dan persentase kerabang telur puyuh. Kualitas kerabang telur dipengaruhi oleh umur puyuh, pakan yang diberikan dan konsumsi pakan (Stadelman \& Cotterill 1977). Puyuh pada perlakuan P2 cenderung memiliki tingkat konsumsi paling rendah dibanding dengan perlakuan lainnya yaitu sebanyak 29,15 $\pm 0,83$ g ekor $^{-1}$ hari ${ }^{-1}$ (Tabel 5). Meskipun bobot kerabang paling kecil, namun persentase kerabang dari perlakuan 2,5\% sari belimbing wuluh masih berada pada kisaran persentase menurut Suci et al. (2019) yaitu 9,48\%-9,78\%.

Rataan bobot dan persentase kerabang telur puyuh pada penelitian disajikan pada Tabel 6 dengan nilai terendah pada perlakuan penambahan 2,5\% sari belimbing wuluh (P2) dan nilai tertinggi pada $5 \%$ sari belimbing wuluh (P3). Hasil penelitian tidak berbeda jauh dari penelitian Nastiti et al. (2014) yang menggunakan puyuh umur 10-12 minggu menghasilkan bobot kerabang antara 1,27 $\pm 0,01 \mathrm{~g}-1,33 \pm 0,06 \mathrm{~g}$ dengan

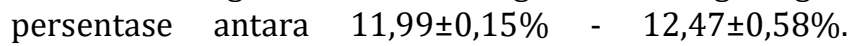
Penambahan sari belimbing wuluh tidak mengganggu proses pembentukan kerabang telur. Belimbing wuluh mengandung berbagai mineral seperti Ca, P, dan I (Kumar et al. 2013). Mineral penyusun kerabang diduga dominan berasal dari pakan yang diberikan. Tingginya konsumsi pakan mempengaruhi bobot dan persentase kerabang telur puyuh. Kualitas kerabang telur dipengaruhi oleh umur puyuh, pakan yang diberikan dan konsumsi pakan (Stadelman \& Cotterill 1977). Puyuh pada perlakuan P2 cenderung memiliki tingkat konsumsi paling rendah dibanding dengan perlakuan lainnya yaitu sebanyak 29,15 $\pm 0,83$ g ekor $^{-1}$ hari $^{-1}$ (Tabel 5). Meskipun bobot kerabang paling kecil, namun persentase kerabang dari perlakuan 2,5\% sari belimbing wuluh masih berada pada kisaran persentase menurut Suci et al. (2019) yaitu 9,48\%-9,78\%.

Indeks kuning telur adalah indikator yang digunakan untuk mengetahui keseragaman telur yang dihasilkan selama pemeliharaan. Data Tabel 5 menunjukkan bahwa indeks telur tidak berbeda nyata pada keseluruhan perlakuan yaitu berkisar antara 75,90 $\pm 1,45$ $78,88 \pm 1,45 \%$. Pemberian sari belimbing wuluh sampai $5 \%$ tidak mempengaruhi keseragaman bentuk telur puyuh yang dihasilkan. Indeks kuning telur puyuh

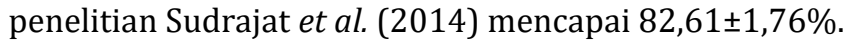
Telur dengan bentuk lonjong memiliki indeks dengan nilai yang rendah dibandingkan dengan telur yang berbentuk lebih bulat (Sudrajat et al. 2014). Menurut Purwati et al. (2015), semakin tinggi kandungan protein dan lemak pakan semakin tinggi pula nilai indeks kuning telur yang dihasilkan.

\section{Aktivitas dan Kapasitas Antoksidan Telur Puyuh}

Menurut Sandrasari (2008), antioksidan merupakan senyawa yang mampu menunda, memperlambat, dan mencegah reaksi oksidasi radikal bebas dalam oksidasi lipid. Adapun senyawa yang diyakini berperan sebagai antioksidan yaitu flavonoid. Kandungan belimbing wuluh yang berperan sebagai antioksidan adalah vitamin $\mathrm{C}$ dan flavonoid. Kandungan vitamin C sebanyak $35 \mathrm{~g}$ dalam 100g belimbing wuluh (Aziz 2016). Flavonoid terdeteksi positif dalam sari belimbing wuluh yang digunakan pada penelitian (Tabel 2).

Berdasarkan hasil yang diperoleh pada Tabel 7, aktivitas dan kapasitas antioksidan semakin menurun dari P1 sampai P3 dan hasil tertinggi pada perlakuan tanpa penambahan sari belimbing wuluh P1. Semakin tinggi dosis sari belimbing wuluh yang diberikan semakin rendah kadar antioksidan kuning telur yang terdeteksi. Penambahan sari belimbing wuluh dengan dosis tertinggi 5\% menghasilkan kuning telur dengan aktivitas dan kapasitas antioksidan terendah dari perlakuan lainnya yaitu 41,54\% dan 23,91 ppm, sedangkan perlakuan tanpa penambahan sari belimbing wuluh (P1) menghasilkan nilai tertinggi yaitu 50,81\% dan 30,77 ppm. Menurut Sandrasari (2008) kapasitas antioksidan suatu bahan terbagi menjadi 3 katergori yaitu sangat kuat jika mampu menghambat radikal bebas lebih dari $80 \%$, sedang jika menghambat $50-80 \%$, dan

Tabel 7 Hasil uji aktivitas dan kapasitas antioksidan

\begin{tabular}{ccc}
\hline Perlakuan & $\begin{array}{c}\text { Aktivitas antioksidan } \\
(\%)\end{array}$ & $\begin{array}{c}\text { Kapasitas antoksidan } \\
(\mathrm{ppm})\end{array}$ \\
\hline P0 & 48,08 & 28,75 \\
P1 & 50,81 & 30,77 \\
P2 & 42,46 & 24,59 \\
P3 & 41,54 & 23,91 \\
\hline
\end{tabular}

P0 = Vita Chick dalam air minum; P1 = air minum tanpa sari belimbing wuluh; P2 $=2,5 \%$ sari belimbing wuluh dalam air minum; P3 $=5 \%$ sari belimbing wuluh dalam air minum 
lemah jika menghambat kurang dari 50\%. Hal tersebut menunjukkan kandungan antioksidan dalam sari belimbing wuluh yaitu vitamin $\mathrm{C}$ dan flavonoid belum berpengaruh optimal terhadap peningkatan kadar antioksidan kuning telur.

Menurut Sunarno \& Djaelani (2018) kadar antioksidan kuning telur dipengaruhi oleh kandungan antioksidan dari suplemen yang diberikan atau dari sintesis antioksidan endogen dalam tubuh puyuh, terutama sistem reproduksi yang dipicu antioksidan eksogen. Senyawa polifenol dapat memicu sintesis antioksidan endogen pada sistem reproduksi puyuh sehingga dapat meningkatkan kadar antioksidan kuning telur. Flavonoid merupakan salah satu senyawa golongan fenol yang berfungsi sebagai antioksidan dan meningkatkan efektivitas vitamin C (Yulianingtyas \& Kusmantoro 2016. Aktivitas antioksidan kuning telur untuk semua perlakuan lebih tinggi dari penelitian Sunarno \& Djaelani (2018) dengan perlakuan suplementasi tepung kulit kayu manis dan daun pegagan yaitu 15,67\%-17,23\%.

\section{SIMPULAN}

Penambahan sari belimbing wuluh dalam air minum puyuh dapat meningkatkan kualitas telur yang ditinjau dari rataan dan bobot kerabang telur, putih telur, dan Haugh Unit namun tidak berpengaruh pada performa puyuh (konsumsi pakan dan air minum, konversi pakan, serta produksi telur). Dosis sari belimbing wuluh 2,5\% menghasilan konversi pakan terendah dengan nilai Haugh Unit tertinggi. Perlakuan sampai dosis paling tinggi belum efektif meningkatkan kadar antioksidan kuning telur. Pada tingkat 5\% sari belimbing wuluh menghasilkan aktivitas dan kapasitas antioksidan terendah sebesar 41,54\% dan 23,91 ppm.

\section{DAFTAR PUSTAKA}

Ardiansyah HR, Sujana \& Tanwiriah W. 2016. Pengaruh pemberian tingkat protein dalam ransum terhadap kualitas telur puyuh (Cortunix-cortunix japonica). Jurnal Universitas Padjajaran. 5 (4): 110.

Aziz NA. 2016. A review of the antimicrobial properties of three selected underutilized fruits of Malaysia. International Journal of Pharmaceutical and Clinical Research. 8 (9): 1278-1283.

Badan Pusat Statistik. 2016. Rata-rata Suhu Udara, Kelembaban, Tekanan Udara, Kecepatan Angin, Curah Hujan dan Penyinaran Matahari Melalui Stasiun Meteorologi Balikpapan, 2015. [Internet]. Diunduh pada : 2016 Nov 19. Tersedia pada : http://bps.go.id

Boling FSDS, Snow JL, Parsons CM \& Baker DH. 2001. The effect of citric acid on the calcium and phosphorus requirement of chicks fed corn-soybean meal diets. Poultry Science 80 (6): 783-788.

Borges SA, Fischer SAV, Maiorka A, Hooge DM \& Cummings KR. 2004 Effect of Diet and cyclic daily heat stress on electrolyte, nitrogen and water intake, excretion and retention by colostomized male broiler chicken. International Journal of Poultry Science. 3 (5) :313321.

Chowdhury R, Islam KMS, Khan MJ, Karim MR, Haque MN, Khatum M \& Pesti GM. 2009. Effect of citric acid, avilamycin, and their combination on the performance, tibia ash, and immune status of broiler. Poultry Science. 88 (8): 1616-1622.

Emma WMSM, Sjofjan 0, Widodo E \& Achmanu. 2013. Karakteristik usus halus ayam pedaging yang diberikan asam jeruk nipis dalam pakan. Jurnal Veteriner. 14 (1):105-110.

Ensminger ME. Oldfield JE \& Heinemann WW. 1990. Feed and Nutrition. California (CA) : The Ensminger Publishing Company Clows.

Fouladi P, Ebrahimnezhad Y, Aghdam SH, Maheri N, \& Ahmadzadeh A. 2018. Effect of organic acids supplement on performance, egg traits, blood serum biochemical parameters and gut microflora in female japanes quail (Qortunix cortunix japonica). Brazilian Journal of Poutry Science. 20 (1): 133-144.

Hamdan H \& Napirah A. 2018. Pengaruh pemberian asam sitrat dalam pakan dengan level protein step down terhadap performans produksi puyuh layer (Cortunix cortunix japonica). Prosiding Seminar Nasional 2018. Kendari (ID): Fakultas Peternakan Universitas Halu Oleo.

Kumar KA, Gousia SK, Anupama M \& Latha JNL. 2013. A review on phytochemical constituents and biological assays of Averrhoa bilimbi. International Journal of Pharmacy and Pharmaceutical Science Research. 3 (4): 136-139.

Lathifah QA. 2008. Uji efektivitas ekstrak kasar senyawa antibakteri pada buah belimbing wuluh (Averrhoa bilimbi L.) dengan variasi pelarut [skripsi]. Malang (ID) : Universitaas Islam Negeri Malang.

Malinda U, Pagala MA \& Napirah A. 2017. Pengaruh pemberian sari belimbing wuluh (Averrhoa bilimbi L.) terhadap performa burung puyuh (Cortunix cortunix japonica) umur 2-6 minggu. Jurnal Ilmu dan Teknologi Peternakan Tropis. 4 (3): 52-58.

Nastiti RA, Hermana W \& Mutia R. 2014. Penggunaan dedak gandum kasar (wheat bran) sebagai pengganti jagung dengan kombinasi tepung daun mengkudu (Morinda citrifolia) untuk menghasilkan telur puyuh sehat rendah kolesterol dan kaya vitamin A. Buletin Makanan Ternak. 101(1): 1-12.

Nuraini S \& Latif SA. 2012. Penampilan dan kualitas telur puyuh yang diberi pakan mengandung produk fermentasi dengan Neurospora crassa. Jurnal Peternakan Indonesia. 14 (2): 385-391.

Peraturan Menteri Pertanian Nomor 05. 2008. Pedoman Budidaya Burung Puyuh yang Baik. [Internet]. [diunduh 2017 Agustus 13]. Tersedia pada: http://perundangan.pertanian.go.id/admin/file/Permentan-0508.pdf

Purwati D, Djaelani MA, \& Yuniawarti EYW. 2015. Indeks kuning telur (IKT), Haugh Unit (HU) dan bobot telur pada berbagai itik lokal di Jawa Tengah. Jurnal Biologi. 4 (2): 1-9.

Putri AAS \& Hidajati N. 2015. Uji aktivitas antioksidan senyawa fenolik ekstrak metanol kulit batang tumbuhan nyiri batu (Xylocarpus molucensis). UNESA Journal of Chemistry. 4(1): 1-6.

Ramdhani MR. 2017. Pengaruh pemberian sari belimbing wuluh (Averrhoa bilimbi L.) terhadap performa puyuh [skripsi]. Bogor (ID) : Instutut Pertanian Bogor.

Sandrasari DA. 2008. Kapasitas antioksidan dan hubungannya dengan nilai total penol ekstrak sayuran indigenous [skripsi]. Bogor (ID): Institut Pertanian Bogor.

Saputra 0 \& Anggraini N. 2016. Khasiat belimbing wuluh (Averrhoa bilimbi L.) terhadap penyembuhan Acne Vularis. Majority. 5 (1): 7680.

Setiawati T, Afnan R \& Ulupi N. 2016. Performa produksi dan kualitas telur ayam petelur pada sistem litter dan cage dengan suhu kandang berbeda. Jurnal Ilmu Produksi dan Teknologi Hasil Peternakan. 4(1): 197-203.

Sipayung PP. 2012.Performa produksi dan kualitas telur puyuh (Cortunix cortunix japonica) pada kepadatan kandang yang berbeda [skripsi]. Bogor (ID) : InstitutPertanian Bogor.

Stadelman WJ \& Cotterill OJ. 1977. Egg Science and Technology. Connecticut (US) : The AVI Publishing Co.Inc.

Sudrajat D, Kardaya D, Dihansih E \& Puteri SFS. 2014. Performa produksi telur burung puyuh yang diberi ransum mengandung kromium organik. Jurnal Ilmu Ternak dan Veteriner. 19(4): 257 262 . 
Subekti E \& Dewi A. 2013. Budidaya puyuh (Cortunix cortunix japonica) di pekarangan sebagai sumber protein hewani dan penambah income keluarga. Jurnal Ilmu Ilmu Pertanian. 9(1):1-10.

Subhadrabandhu S. 2001. Under-Utilized Tropical Fruits of Thailand Bangkok (TH): Meetings and Publications Officer, FAO Regional Office for Asia and the Pacific.

Suci DM, Nuha NU \& Suryahadi. 2019. Pemberian ekstrak daun kemuning (Murraya paniculata (L.) Jack) dalam air minum terhadap performa dan kualitas fisik telur puyuh malon. Jurnal Ilmu Nutrisi dan Teknologi Pakan. 17 (3): 73-77.

Sunarno \& Djaelani MA. 2018. Suplementasi tepung kulit kayu manis dan daun pegagan dalam pakan terhadap kandungan kolesterol dan antioksidan telur puyuh (Cortunix cortunix japonica). Bioma. 7 (1): 65-81.

Tamzil MH. 2014. Strespanas pada unggas : metabolisme, akibat, dan upaya penanggulangannya. Wartazoa. 24(2):57-66.

Tangkanakul P, Auttaviboonkul P, Niyomwit B \& Lowvitoon N. 2009. Antioxidant capacity, total phenolic content and nutritional composition of Asian foods after thermal processing. International Food Research Journal. 16: (571-580).

Thamizhselvam N, Liji IV, Sanjayakumar YR, Sanal GCG, Kumar VKG \& Swamy GK. 2015. Evaluation of antioxidant activity of Averrhoa bilimbi Linn. fruit juice in paracetamol intoxicated wistar albino rats. Enliven: Toxicol Allied Clin Pharmacol. 1(1):1-6.

Widyastuti W, Mardiati SM \& Saraswati TR. 2014. Pertumbuhan puyuh (Cortunix cortunix japonica) setelah pemberian tepung kunyit (Curcuma longa L.) padapakan. Buletin Anatomi dan Fisiologi. 22 (2): $12-20$.

Yulianingtyas A \& Kusmantoro B. 2016. Optimasi volume pelarutan dan waktu maserasi pengambilan flavonoid daun belimbing wuluh (Averrhoa bilimbi L). Jurnal Teknik Kimia. 10 (2):58-64. 